Anaesthesist 2013 $62: 543-548$

DOI 10.1007/s00101-013-2179-5

Received: 23 January 2013

Revised: 19 March 2013

Accepted: 18 April 2013

Published online: 15. Mai 2013

๑) Springer-Verlag Berlin Heidelberg 2013

\author{
I. Balga ${ }^{1,4} \cdot$ H. Gerber ${ }^{1} \cdot$ X.H. Schorno ${ }^{2} \cdot$ F. Aebersold Keller ${ }^{3} \cdot$ H.-P. Oehen ${ }^{3}$ \\ ${ }^{1}$ Department of Anaesthesiology, Surgical Intensive Care, Emergency Care Medicine and Pain Medicine, \\ Kantonsspital Lucerne \\ 2 Pharmacy, Kantonsspital Lucerne \\ ${ }^{3}$ Department of Pathology, Kantonsspital Lucerne \\ ${ }^{4}$ Department of Anaesthesiology and Intensive Care Medicine, Heartcenter Leipzig, University of Leipzig
}

\title{
Bupivacaine crystal deposits after long-term epidural infusion
}

tumor infiltration into the retroperitoneal space. The only other relevant fact from the medical history was smokingrelated chronic obstructive pulmonary disease (COPD). Initially the carcinoma was diagnosed as grade pT3pN2M0. After surgical excision of the carcinoma the patient had been asymptomatic until a recurrence of the tumor was found on follow-up computed tomography (CT) 1 year later. The patient suffered from upper quadrant abdominal pain and the initial analgesia with acetaminophen, oral morphine and a corticosteroid was inadequate. Subsequently ethanol neurolysis of the celiac plexus was performed, although this also failed to improve pain control. A tunnelled EC (Tuohy $18-G$ peridural needle and catheter, Perifix, Braun, Melsungen, Germany) was placed at thoracic spinal level $7 / 8$. The correct location of the EC was confirmed by injection of $3 \mathrm{ml}$ lidocaine $2 \%$ with epinephrine $(1: 200,000)$ and the pin-prick method which resulted in a change in thoracic sensory level to the pin-prick from 4 to 12 . The epidural infusion was started with a mixture of bupivacaine $\mathrm{HCl} 0.25 \%$ and morphine $\mathrm{HCl} 0.005 \%$ in a $1,000 \mathrm{ml}$ bag via a portable, battery powered electronic pump at $6 \mathrm{ml} \mathrm{h}^{-1}$ [39]. The infusion solution was prepared from stock solution of bupivacaine by the hospital pharmacy of the Kantonsspital Lucerne. The solution was adjusted to $\mathrm{pH}$ 5.5-6.0 with $\mathrm{NaOH}$. The daily administered doses amounted to $360 \mathrm{mg}$ bupivacaine $\mathrm{HCl}$ and $7.16 \mathrm{mg}$ morphine $\mathrm{HCl}$. The daily infusion volume of the LA mixture was $144 \mathrm{ml}$. With this therapy the patient's pain severity was reduced so that only occasional mild adenocarcinoma suffered from severe upper quadrant abdominal pain due to

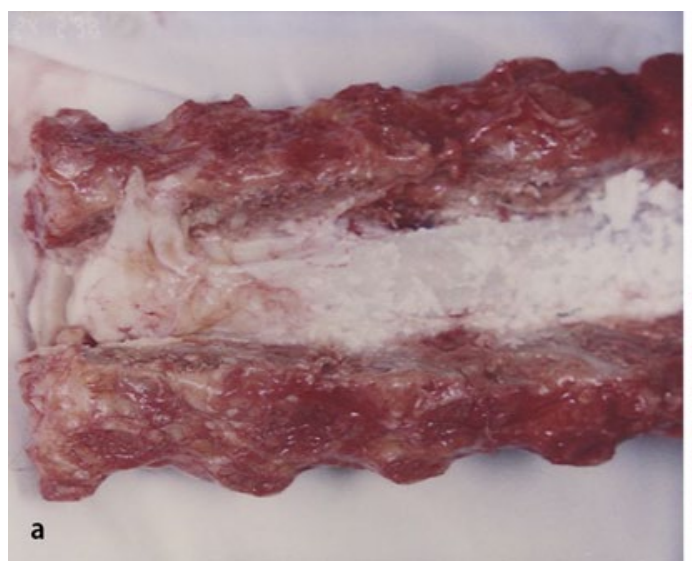

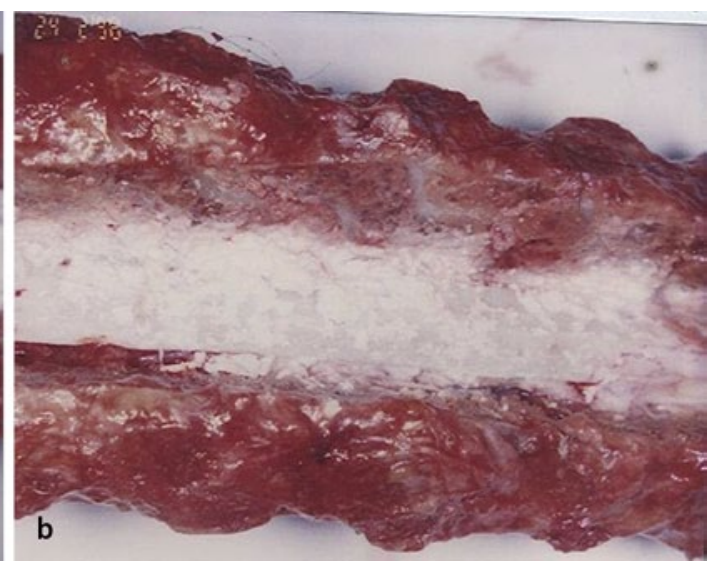

Fig. $1<$ a,b Autopsy of the thoracic spine (two different locations) showing white crystalline deposits in the epidural space 


\section{Originalien}
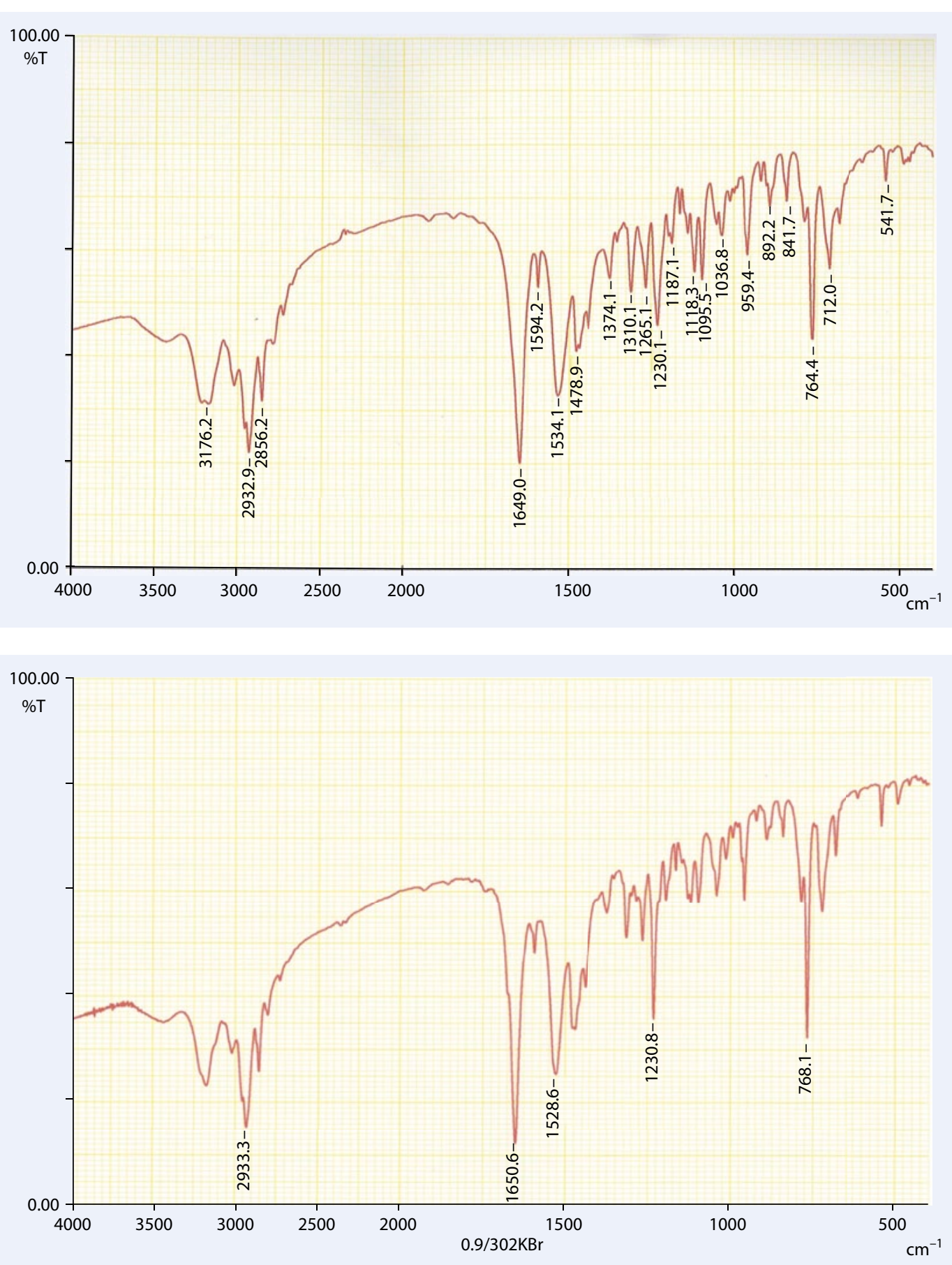

Fig. $2 \varangle$ Reference spectrum of bupivacaine base (red curve)
Fig. $3<$ Infrared spectrum of the crystalline deposits (red curve) in the thoracic epidural space abdominal pain occurred and the patient was discharged and treated as an outpatient. However, 3 months later the severity of the pain increased and infusion concentrations were doubled to bupivacaine $\mathrm{HCl} 0.5 \%$ and morphine $\mathrm{HCl} 0.01 \%$ and the infusion rate halved to $3 \mathrm{ml} \mathrm{h}^{-1}$ (daily infusion volume $72 \mathrm{ml}$ ); therefore the administered total daily dose remained the same (bupivacaine $\mathrm{HCl} 360 \mathrm{mg}$ and morphine $\mathrm{HCl} 7.13 \mathrm{mg}$ ). The patient died 6 months after initiation of epidural anesthesia with the EC still in place. An autopsy was performed to examine the spinal canal. The total administered dose over 6 months (192 days) amounted to $69 \mathrm{~g}$ of bupivacaine $\mathrm{HCl}$ and to $1.37 \mathrm{~g}$ of morphine $\mathrm{HCl}$. The EC provided effective pain relief and the patient did not report any adverse neurological symptoms or other complications from the epidural analgesia during this period. The EC was never changed but the catheter insertion site was regularly inspected and was free from any skin reaction or infection.

\section{Results}

The autopsy revealed extensive large white crystalline deposits in the epidural space extending from thoracic level 4 to 8 (- Fig. 1a,b). 
These deposits and the reference bupivacaine base (derived from commercial bupivacaine $\mathrm{HCl}$, Schweizerhall, Basel, Switzerland) were analyzed by infrared spectrometry (infrared spectrometer: Paragon 500 FT-IR, Perkin Elmer, Schwerzenbach, Switzerland). The analysis was performed on potassium bromide pellets. The spectrum of bupivacaine base derived in the pharmacy laboratory from commercial bupivacaine $\mathrm{HCl}$ served as the reference (• Fig. 2).

The spectrum of the crystalline deposits is presented in $\bullet$ Fig. 3 .

Both spectra in the same picture (- Fig. 4) illustrate strong similarities.

The correlation coefficient between both spectra was automatically calculated by the infrared spectrometer and showed a high correlation (coefficient 0.973) which indicated that the crystalline deposits could be identified as bupivacaine base.

The spectrum of morphine base derived in the pharmacy laboratory from commercial morphine $\mathrm{HCl}$ (Hänseler, Herisau, Switzerland) served as the reference (• Fig. 5).

There was no similarity between the spectrum of bupivacaine base deposits and the spectrum of morphine base (• Fig. 6).

No morphine base or morphine $\mathrm{HCl}$ could be detected either by infrared spectrometry or by thin-layer chromatography (TLC).

A histological examination was performed and 0 Fig. 7 gives an overview showing the crystalline deposits as a bright pink eosinophilic material on the left side surrounded by soft tissue and mainly by fat tissue (dark pink) on the right side.

The soft and fat tissue contained some calcified tissue corresponding to splintered bone fragments. Crystals with double light refraction could not be seen in the polarised light. A detail image of necrotic adipocytes within the crystalline material is shown in - Fig. 8. Nerve tissue could not be differentiated from the crystalline tissue and was not identified within or without the crystalline deposits (• Fig. 8).

Anaesthesist 2013 · 62:543-548 DOI 10.1007/s00101-013-2179-5

C) Springer-Verlag Berlin Heidelberg 2013

\section{Balga · H. Gerber $\cdot$ X.H. Schorno · F. Aebersold Keller $\cdot$ H.-P. Oehen Bupivacaine crystal deposits after long-term epidural infusion}

\section{Abstract}

The case of a 45-year-old male patient (body weight $52 \mathrm{~kg}$, height $1.61 \mathrm{~m}$ ) with a locally invasive gastric carcinoma infiltrating into the retroperitoneal space is reported. Because of severe cancer pain a tunnelled thoracic epidural catheter (EC) was placed at thoracic spinal level $7 / 8$ and a local anesthetic (LA) mixture of bupivacaine $0.25 \%$ and morphine $0.005 \%$ was infused continuously at $6 \mathrm{ml} \mathrm{h}^{-1}$. To optimize pain therapy the concentration was doubled (bupivacaine $0.5 \%$, morphine $0.01 \%) 3$ months later but the infusion rate was reduced to $3 \mathrm{ml} \mathrm{h}^{-1}$ thus the total daily dose did not change. The patient died 6 months after initiation of the epidural analgesia from the underlying disease. The total amount of bupivacaine infused was $69 \mathrm{~g}$ and of morphine $1.37 \mathrm{~g}$. The patient never report- ed any neurological complications. The autopsy revealed large white crystalline deposits in the thoracic epidural space which were identified as bupivacaine base by infrared spectrometry. Morphine could not be detected. A histological examination showed unreactive fatty tissue necrosis within the crystalline deposits but nerve tissue could not be identified. It is concluded that the bupivacaine crystalline deposits arose due to precipitation but the clinical significance with regard to sensory level and neuraxial tissue toxicity is unknown.

Keywords

Epidural catheter - Local anaesthetic agent . Bupivacaine $\cdot$ Precipitation · Pain therapy

\section{Bupivacainkristalle nach epiduraler Langzeitinfusion}

\section{Zusammenfassung}

Berichtet wird über einen 45-jährigen Patienten (Körpergewicht 52 kg, Körpergröße 1,61 m) mit lokal invasivem, das Retroperitoneum infiltrierendem Magenkarzinom. Wegen starker Tumorschmerzen wurde ein getunnelter Epiduralkatheter auf der Höhe Th7/8 zur kontinuierlichen Infusion $(6 \mathrm{ml} / \mathrm{h})$ einer lokalanästhetisch wirkenden Kombination aus 0,25\%igem Bupivacain und 0,005\%igem Morphin gelegt. Zur Therapieoptimierung wurden 3 Monate später die Konzentration verdoppelt ( $0,5 \%$ iges Bupivacain und $0,01 \%$ iges Morphin) und die Infusionsrate halbiert ( $3 \mathrm{ml} / \mathrm{h}$ ), sodass sich die tägliche Dosis nicht veränderte. Sechs Monate nach Beginn der Epiduralanalgesie verstarb der Patient an seiner Grunderkrankung. Insgesamt waren $69 \mathrm{~g}$ Bupivacain und $1,37 \mathrm{~g}$ Morphin infundiert worden. $\mathrm{Zu}$ keiner Zeit hatte der Patient neurologische
Komplikationen angegeben. In der Autopsie fanden sich großflächige weiße kristalline Ablagerungen im thorakalen Epiduralraum, infrarotspektrometrisch erwiesen sich diese als aus Bupivacain bestehend. Morphin konnte nicht nachgewiesen werden. Die histologische Untersuchung zeigte eine nichtreaktive Fettgewebsnekrose innerhalb der Bupivacainkristalle; Nervengewebe ließ sich nicht identifizieren. Es wird davon ausgegangen, dass die Bupivacainkristalle durch Präzipitation entstanden sind. Nicht bekannt ist ihre klinische Bedeutung auf sensorischer Ebene und hinsichtlich einer neuroaxialen Gewebetoxizität.

Schlüsselwörter

Epiduralkatheter · Lokalanästhetikum · Bupivacain · Präzipitation · Schmerztherapie

\section{Discussion}

Of cancer patients $10-15 \%$ fail to achieve sufficient analgesia from oral medications mainly due to tolerance to the analgesic effect of opioids and the occurrence of opioid-related side effects following dose escalation. At this point interventional pain therapy, such as epidural analgesia can be introduced with much greater efficacy [12]. Tissue toxicity to LA has been documented in animal studies particularly at higher concentrations $[2,3,4,6,7,8$, $11,13,14,15,16,17,18,19,20,25,29,31,32$, $33,34,37,38$ ] but seldom observed using the recommended clinical concentrations in humans $[1,15,22,23,24,26,28,31]$.

Analgesia provided by LA agents administered neuraxially can often be augmented by the addition of adjuvants, such as opioids (morphine) and alpha agonists (clonidine; [12]). Different LA mixtures or 


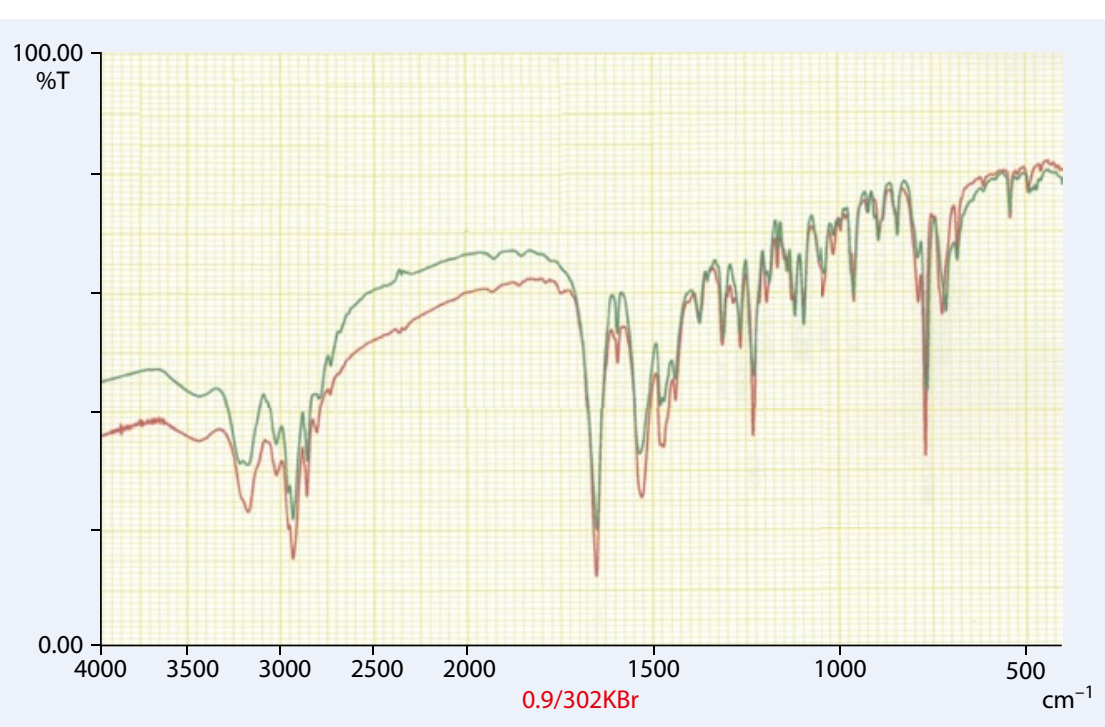

Fig. $4 \Delta$ Infrared spectrum of bupivacaine base (green curve) serves as the reference and infrared spectrum of the crystalline deposits (red curve) correlates highly with the reference (correlation coefficient 0.973)

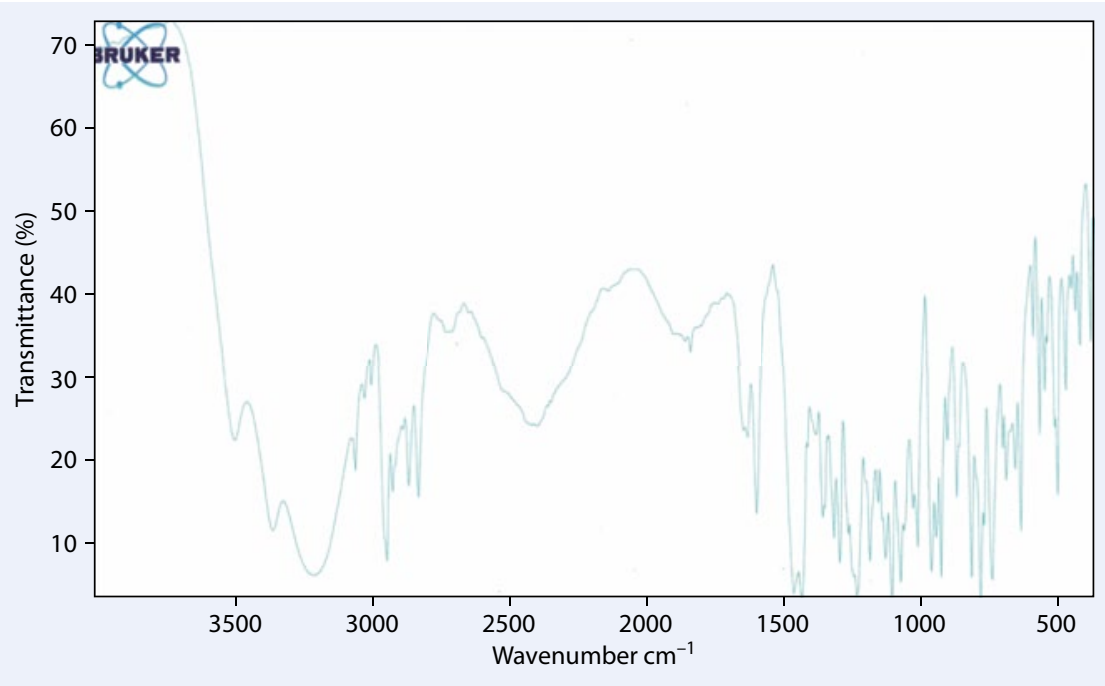

Fig. $5 \Delta$ Infrared spectrum of morphine base (blue curve)

LA without supplements have not been extensively examined for local tissue damage in humans [31] apart from a few case reports $[1,15,22,23,24,26,28]$. To explain the mechanism of tissue toxicity various pathophysiological pathways of LA or LA mixtures in different human and animal tissues, such as skin, soft tissue, muscle and neurological tissue are discussed but the pathogenesis has not been elucidated in detail $[1,13,19,20,29,32,33,34,35,36$, 37, 38]. Particularly, only limited information is available on the extended epidural administration of continuous infusion of LA or LA mixtures for weeks and months. the $\mathrm{pH}$ has to be kept well below the $\mathrm{pKa}$, usually between 5.5. and 6.0. (3) When a bupivacaine $\mathrm{HCl}$ solution is infused the body buffering capacity (protein, bicarbonate) adjusts the $\mathrm{pH}$ close to the physiological range of $\mathrm{pH} 7.4 \pm 0.05$ which predisposes bupivacaine $\mathrm{HCl}$ to precipitate [39]. Contrary to lidocaine the in vitro titration of bupivacaine to a higher $\mathrm{pH}$ is very critical and results invariably in precipitation of the drug $[1,21,39]$. Considering these facts there are several situations in which the precipitation of bupivacaine in vivo may arise: (1) the $\mathrm{pH}$ of the LA solution rapidly changed to a higher $\mathrm{pH}$ value after infusion into the epidural space. (2) The underlying disease (cancer) could have altered the solubility of the bupivacaine-morphine solution with regard to tissue $\mathrm{pH}$, tissue buffer capacity and protein binding [16]. The cancer could have diminished the proportion of protein-bound drug and thus made it more prone to precipitation. (3) The EC as a foreign body in the epidural space could serve as a facilitator of precipitation. (4) In the second period of pain therapy the concentrations were doubled to bupivacaine $\mathrm{HCl} 0.5 \%$, morphine $\mathrm{HCl} 0.01 \%$ and the infusion rate halved to $3 \mathrm{ml} \mathrm{h}^{-1}$. The lower infusion rate and the higher concentration of the drug could possibly lead to a more rapid adjustment of the tissue to $\mathrm{pH} 7.4$ thereby favoring precipitation. Taken together, the type of drug, the concentration, composition, the physicochemical properties of the drug, interactions with human tissue, the interaction of the EC as foreign body in human tissue, the speed of infusion into the epidural space and the long-term administration of the LA mixture could favor precipitation with subsequent tissue damage [1]. In this case morphine base or morphine $\mathrm{HCl}$ in the crystals could not be detected by infrared spectrometry (because the quantity was too small or due to complete resorption). In a similar case morphine $\mathrm{HCl}$ could be demonstrated by chemical analysis in such LA mixture deposits [1]. Morphine does not alter the $\mathrm{pH}$ or solubility of LA mixtures $[5,16]$. The stability and compatibility of such LA mixtures are proven to be safe in infusion systems [5, $9,14,16,30]$ and safe when used clinically [14]. On the contrary this case and anoth- 


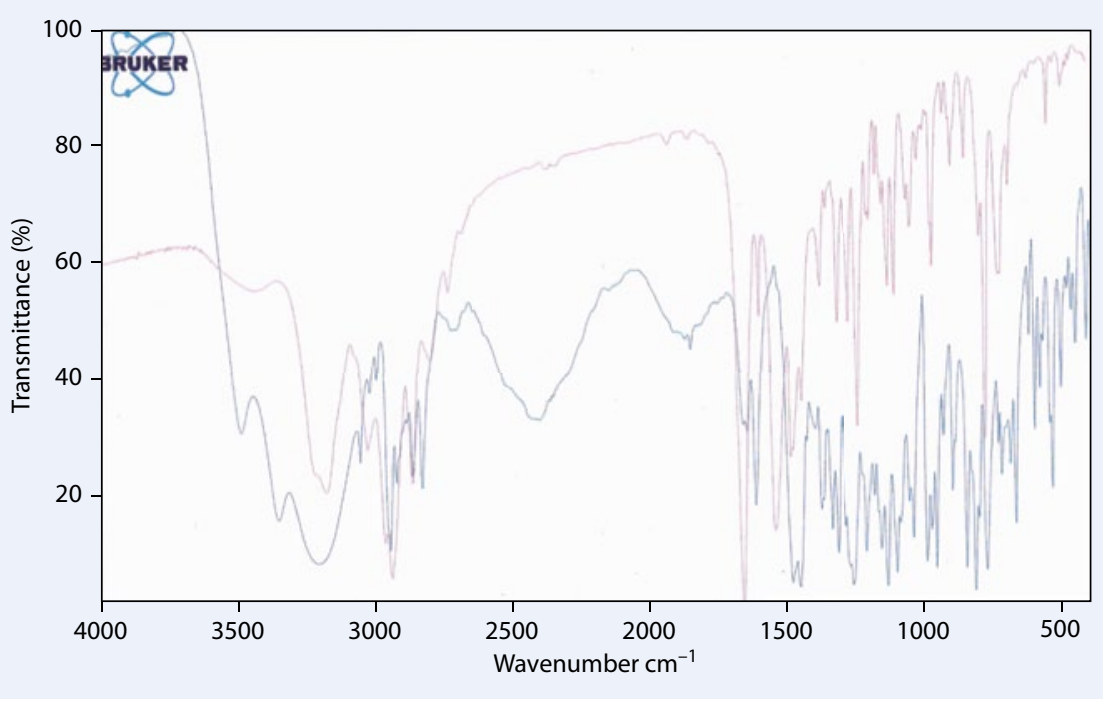

Fig. $6 \Delta$ Spectrum of bupivacaine base (upper or violet curve) showing no similarity to the spectrum of morphine base (lower or blue curve). Both spectra were derived with the infrared spectrum software (OPUS 6.5, FT-IR Alpha-T, Bruker Optics, Billerica MA)

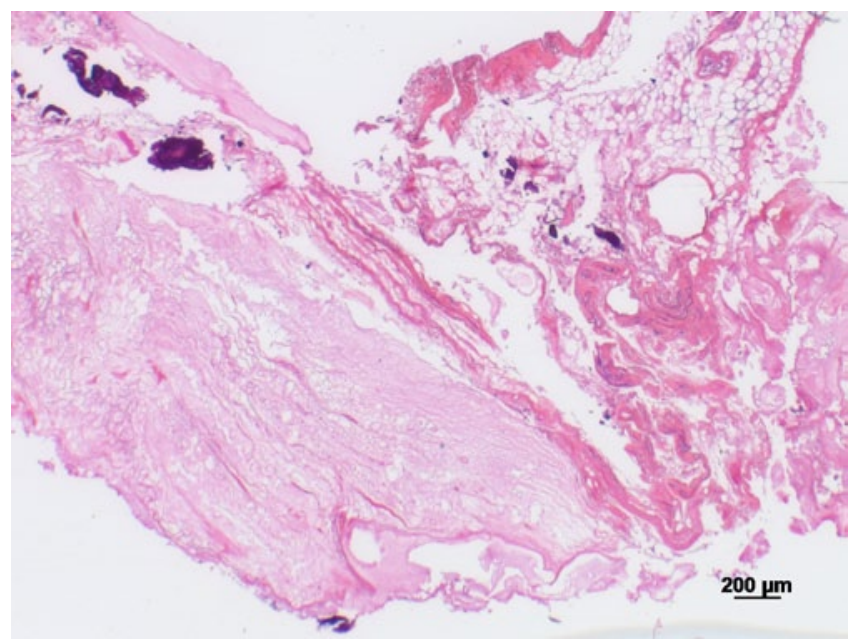

Fig. $7<$ Histological section of epidural space, thoracic level 4 to 8 . Amorphous, pale eosinophilic material is seen on the left (crystalline deposits) beside the fat and soft tissue (dark pink) on the right side of the picture.

There was no substantial inflammatory reaction (HE staining, magnification $\times 25$ )

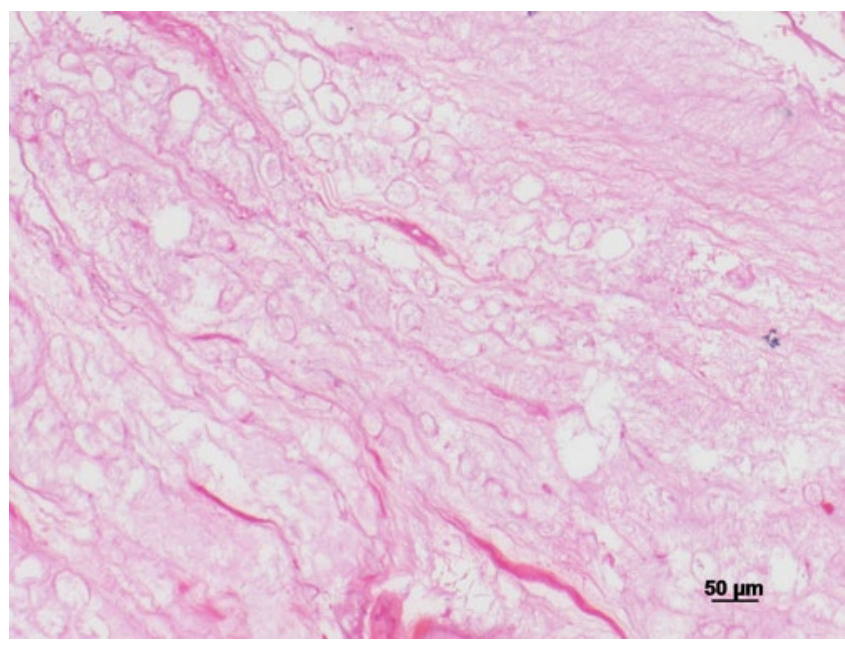

Fig. $8<$ Histological section of epidural space, thoracic level 4 to 8 . Individual partial image areas show fatty tissue necrosis within the pale eosinophilic material (HE staining, magnification $\times 100$ )

er case report [1] discovered bupivacaine deposits with unreactive necrosis in dif- ferent human tissues (e.g. epidural space, skin, subcutaneous tissue, muscle and soft tissue) after long-term continuous infusion of bupivacaine-morphine mixtures. In this case, the histological examination revealed fatty tissue necrosis within the bupivacaine deposits. Nerve tissue within or outside the deposits could not be identified. In the formerly published case [1] soft tissue necrosis developed after dislocation of the thoracic EC into the paraspinal space with continued inadvertent administration of bupivacaine-morphine solution [1]. After removal of the EC the same initial thoracic sensory level 4-12 on both sides persisted until the patient died several weeks later. As the CT scan of the thoracic spine showed no signs of myelon compression, it can be speculated that this terminally-ill patient had paraspinal tissue necrosis with crystalline bupivacaine deposits in addition to epidural deposits similar to the ones found in this case. These deposits could possibly maintain segmental analgesia in these patients. A nerve tissue damage by long-term epidural application of LA or LA mixtures cannot be excluded. If the patient would have lived for a longer period and the epidural analgesia continued, it could be speculated that compression of the myelon due to crystalline growth or direct toxic effects on nerve tissue could occur. To the best of the authors' knowledge, there is presently no information on using imaging techniques to detect similar epidural deposits. It is not known how common such small deposits are during long-term epidural infusion, whether they are specific for bupivacaine and how they affect epidural analgesia.

\section{Conclusions}
A mixture of bupivacaine and mor- phine may cause crystalline precipita- tion and result in tissue damage or unre- active necrosis. Damage of nervous tis- sue by these LA crystal deposits after long-term use cannot be excluded. Local tissue inflammation in addition to a for- eign body, such as an EC might induce small local deposits of the LA mixture, to serve as a nidus for crystalline forma- tion. The exact time period after which the LA deposits start to form is unknown but could be important for predicting the safety margin of long-term LA use. 


\section{The possibility of LA precipitation in the neuraxial space or other tissue should also be considered.}

\section{Corresponding address}

\section{Dr. I. Balga}

Department of Anaesthesiology and Intensive Care Medicine, Heartcenter Leipzig,

University of Leipzig

Strümpellstr. 39, 04289 Leipzig

Germany

ingrid.balga@gmail.com

Acknowledgment. The authors thank Mr. Maurice Hogan, M.D., and Mr. Menish Soni, M.D., for excellent support.

Conflict of interest. The corresponding author states that there are no conflicts of interest.

\section{References}

1. Balga I, Gerber H, Konrad C, Diebold J (2009) Entwicklung eines Weichteilulkus nach periduraler Langzeitinfusion. Anaesthesist 58:156-162

2. Basson MD, Carlson BM (1980) Myotoxicity of single and repeated injections of mepivacaine (Carbocaine) in the rat. Anesth Analg 59:275-282

3. Benoit PW, Belt WD (1970) Destruction and regeneration of skeletal muscle after treatment with a local anaesthetic, bupivacaine (Marcaine). J Anat 107:547-556

4. Benoit PW (1978) Reversible skeletal muscle damage after administration of local anesthetics with and without epinephrine. J Oral Surg 36:198-201

5. Bianchi F, Ginggen A, Tardy Y (2008) Stability and compatibility of drug mixtures in an implantable infusion system. Anaesthesia 63:972-978

6. Carlson BM, Emerick S, Komorowski TE et al (1992) Extraocular muscle regeneration in primates. Local anesthetic-induced lesions. Ophthalmology 99:582-589

7. Carlson BM, Rainin EA (1985) Rat extraocular muscle regeneration. Repair of local anesthetic-induced damage. Arch Ophthalmol 103:1373-1377

8. Carlson BM, Shepard B, Komorowski TE (1990) A histological study of local anesthetic-induced muscle degeneration and regeneration in the monkey. J Orthop Res 8:485-494

9. Classen AM, Wimbish GH, Kupiec TC (2004) Stability of admixture containing morphine sulphate, bupivacaine hydrochloride, and clonidine hydrochloride in an implantable infusion system. J Pain Symptom Manage 28:603-611

10. Coyle N, Adelhardt J, Foley KM, Portenoy RK (1990) Character of terminal illness in the advanced cancer patient: pain and other symptoms during the last 4 weeks of life. J Pain Symptom Manage 2:83-

11. Foster AH, Carlson BM (1980) Myotoxicity of local anesthetics and regeneration of the damaged muscle fibers. Anesth Analg 59:727-736

12. Gerheuser F, Roth A (2007) Periduralanästhesie. Anaesthesist 56:499-526
13. Hall-Craggs EC (1980) Early ultrastructural changes in skeletal muscle exposed to the local anaesthetic bupivacaine (Marcaine). Br J Exp Pathol 61:139149

14. Hildebrand KR, Elsberry DD, Deer TR (2001) Stability, compatibility, and safety of intrathecal bupivacaine administered chronically via an implantable delivery system. Clin J Pain 17:239-244

15. Hogan Q, Dotson R, Erickson S et al (1994) Local anesthetic myotoxicity: a case and review. Anesthesiology 80:942-947, Rev 71:849-908

16. Johnson CE (1997) Compatibility of bupivacaine hydrochloride and morphine sulfate. Am J Health Syst Pharm 54:61-64

17. Komorowski TE, Shepard B, Okland S, Carlson BM (1990) An electron microscopic study of local anesthetic-induced skeletal muscle fiber degeneration and regeneration in the monkey. J Orthop Res 8:495-503

18. Kyttä J, Heinonen E, Rosenberg PH et al (1986) Effects of repeated bupivacaine administration on sciatic nerve and surrounding muscle tissue in rats. Acta Anaesthesiol Scand 30:625-629

19. Nagaro T, Arai T (1993) Comments on injectate encapsulation after long-term epidural administration. Pain 55:125-126

20. Nonaka I, Takagi A, Ishiura S et al (1983) Pathophysiology of muscle fiber necrosis induced by bupivacaine hydrochloride (Marcaine). Acta Neuropathol 60:167-174

21. Peterfreund RA, Datta S, Ostheimer GW (1989) pH adjustment of local anesthetic solutions with sodium bicarbonate: laboratory evaluation of alkalinisation and precipitation. Reg Anesth 14:265-270

22. Parris WC, Dettbarn WD (1988) Muscle atrophy following nerve block therapy. Anesthesiology $69 \cdot 289$

23. Rao VA, Kawatra VK (1988) Ocular myotoxic effects of local anesthetics. Can J Ophthalmol 23:171-173

24. Schipper I, Lüthi M (1994) A case of diplopia after retrobulbar anesthesia for cataract operation. Klin Monatsbl Augenheilkd 204:176-180

25. Schultz E, Lipton BH (1978) The effect of marcaine on muscle and non-muscle cells in vitro. Anat Rec 191:351-369

26. Selander D, Edshage S, Wolff T (1979) Paresthesiae or no paresthesiae? Nerve lesions after axillary blocks. Acta Anaesthesiol Scand 23:27-33

27. Smith TJ, Coyne PJ, Staats PS et al (2005) An implantable drug delivery system (IDDS) for refractory cancer pain provides sustained pain control, less drug-related toxicity, and possibly better survival compared with comprehensive medical management (CMM). Ann Oncol 16:825-833

28. Taylor G, Devys JM, Heran F, Plaud B (2004) Early exploration of diplopia with magnetic resonance imaging after peribulbar anaesthesia. $\mathrm{Br} J$ Anaesth 92:899-901

29. Wakata N, Sugimoto H, Iguchi H (2001) Bupivacaine hydrochloride induces muscle fiber necrosis and hydroxyl radical formation - dimethyl sulphoxide reduces hydroxyl radical formation. Neurochem Res 26:841-844

30. Wulf H, Gleim M, Mignat C (1994) The stability of mixtures of morphine hydrochloride, bupivacaine hydrochloride, and clonidine hydrochloride in portable pump reservoirs for the management of chronic pain syndromes. J Pain Symptom Manage 9:308-311

31. Yagiela JA, Benoit PW, Buoncristiani RD et al (1981) Comparison of myotoxic effects of lidocaine with epinephrine in rats and humans. Anesth Analg 60:471-480
32. Zink W, Bohl JRE, Hacke N et al (2005) The longterm myotoxic effects of bupivacaine and ropivacaine after continuous peripheral nerve blocks. Anesth Analg 101:548-554

33. Zink W, Graf BM (2003) Toxikologie der Lokalanästhetika. Anaesthesist 52:1102-1123

34. Zink W, Graf BM (2004) Local anesthetic myotoxicity. Reg Anesth Pain Med 29:333-340

35. Zink W, Graf BM, Sinner B et al (2002) Differential effects of bupivacaine on intracellular $\mathrm{Ca}^{2+}$ regulation: potential mechanisms of its myotoxicity. Anesthesiology 97:710-716

36. Zink W, Missler G, Sinner B et al (2005) Differential effects of bupivacaine and ropivacaine enantiomers on intracellular $\mathrm{Ca}^{2+}$ regulation in murine skeletal muscle fibers. Anesthesiology 102:793798

37. Zink W, Seif C, Bohl JR et al (2002) The acute myotoxic effects of bupivacaine and ropivacaine after continuous peripheral nerve blockades. Anesth Analg 97:1173-1179

38. Zink W, Sinner B, Zausig Y, Graf BM (2007) Myotoxizität von Lokalanästhetika. Anaesthesist 56: 118-127

39. Arzneimittel-Kompendium der Schweiz (2012) Bupivacain HCL (Sintetica, Mendrisio, Switzerland) Morphin HCL (Streuli Pharma AG, Uznach, Switzerland). Documed AG, Basel (http://www.documed. ch) 